\title{
Education and Health in ICT-futures: Scenarios and sustainability impacts of ICT societies
}

\author{
Luciane Aguiar Borges \\ Division of Environmental Strategies Research - fms \\ Centre for Sustainable Communications - CESC \\ $\mathrm{KTH}$ - Royal Institute of Technology \\ Stockholm, Sweden \\ luciane.borges@abe.kth.se
}

\begin{abstract}
This study explores the performance of the education and health sectors in relation to five ICT futures for Sweden in 2060. The accessibility, affordability, quality and efficiency of these sectors influence the creation and maintenance of essential collective values such as democracy and justice; consequently both education and health are fundamental to a sustainable society. Exploring the performance of these sectors in different futures enables the identification of barriers and undesirable developments, and encourages a debate on how ICT can be used to reinforce inclusive, and counteract unwanted, futures.
\end{abstract}

Keywords_education; health; ICT; futures; sustainability

\section{INTRODUCTION}

Many studies claim a positive relationship between ICT and sustainable development. ICT has led to new ideas and business models and it is regarded as a means of overcoming segregation [1] of supporting energy efficiency [2] and of saving natural resources [3] among other benefits. Nevertheless, the incredibly fast pace in which technological innovations are transforming important sectors of society has led to unexpected consequences. For example, a multitude of digital divides have emerged between those who are able to fully enjoy the advantages of ICT and those who are not [4]. The tension between rapid implementation of ICT and long term consequences for society calls for methods that enable the exploration of how societies may look in the future, and thus support discussions on how ICT could be used towards sustainable futures.

Futures studies and scenarios offer an effective method of dealing with uncertainties. This is an important step in successfully coping with transition towards sustainable development [5]. The use of scenarios helps to explore possible developments and identify benefits and drawbacks of technological innovations that are unforeseen today and thus may empower actors who play a role in shaping and implementing ICT strategies and policies.

This study aims to explore the performance of education and health in relation to five scenarios for Sweden in 2060. These services are fundamental to the sustainable functioning of society. The accessibility, affordability, quality and efficiency of these sectors influences the creation and maintenance of universal values and principles such as democracy [6] [7] and justice [8]. Exploring the performance of these services in different futures enables the identification of barriers and undesirable developments and enhances a discussion on how ICT can be used to reinforce inclusive, and counteract unwanted, futures.

In spite of many studies examining the use of ICT in education [9] [10] and health [11], few studies have focused on the use of ICT in these sectors as concerns sustainability. Conversely, most scenarios for sustainability focus on fulfilling targets for energy consumption and carbon emissions [12] and do not directly address these sectors. The scenario elements for education and health presented in this study may contribute to bridging this gap. The development of the scenario elements was one of many steps on the path to constructing comprehensive descriptions of ICT 2060 futures for Sweden. The process included literature studies and a workshop with the participation of academics and practitioners in the ICT sector.

This study is expected to encourage debate and advance understanding about what sustainability could mean within the interdisciplinary field in which ICT is embedded. In addition to triggering discussion on how different ICT developments might change the provision and consumption of these services in the future, it is also expected to shed light on different strategies and decision making that could lead to more sustainable transitions for these sectors into the information society.

\section{EDUCATION AND HEALTH IN SWEDEN}

In spite of growing privatisation since the 1990s, the Swedish government still keeps primary control of the provision and maintenance of education and health. Sweden is also among the European countries that lead in the implementation of ICT solutions in these areas [13] [14]

Since 1970, the Swedish Government and the Knowledge Foundation (KKS) has financed many projects that deal with the use of ICT in education. Computer-in-school projects were implemented during 1970s and 1980s. In 1994 the Government formed an IT Commission that developed the document 'Information Technology - Wings to Human Ability' that allocated the responsibility for implementing strategies for use of ICT in schools to municipalities [15]. Since $1995 \mathrm{KKS}$ has enhanced the use of ICT in schools by supporting several related projects [15]. Another example was the National Programme for ICT in Schools (ItiS) implemented from 1999 
to 2002. This programme focused on the instruction of teachers and the development of strategies for Internet access in schools. Between 2005 and 2010, the government allocated resources for the expansion of ICT in teaching.

However, only in 2010 with the new reform that governs Swedish Schools (School Act, 2010:800) was ICT included in the syllabus as a common subject to all upper secondary schools and acknowledged as a means to enhance education [16]. This late inclusion of ICT in educational policies suggests that technologies have not changed education to the same extend as they have in other sectors (e.g. banking). An interview with a Deputy Principal of an upper secondary school in Stockholm also revealed that ICT has been used as a tool for management (e.g. an interface for communication between teachers and students) but it has been used only weakly as a learning tool (Interview performed on December 2013). Häggmark [17] pinpoints that the lack of common standards has prevented distance learning. The number of students in higher education studying exclusively through distance courses and programmes declined by $12 \%$ between 2011 and 2013. [18].

In relation to health, Sweden and the Nordic Countries are pioneers and quite successful in implementing eHealth solutions [14]. Since 2008, the government has implemented the National Patient Overview (NPÖ), which allows registering and updating of information about patient's personal data, care contacts, chronic disease diagnoses, test results and a list of dispensed drugs. This system is quite important for the management of the sector since citizens can seek treatment anywhere in the country. [19]

The National ePrescription has also been a common routine in Sweden. The system transfers prescriptions directly from the physicians' office to pharmacies electronically. Sweden is quite advanced in the development and implementation of standards and is also a member of the International Health Terminology Standard Development Organisation (IHTSDO). Telemedicine is widespread in the country and most of hospitals offer teleconsultation (doctor-to-patient) and distance monitoring [19].

As concerns healthcare governance there is a good integration between national, regional and local levels. The county councils are increasingly using ICT and developing processes related to eHealth. For example the counties have developed a join action plan to further develop their coordination (Center for eHealth in Sweden - CEHis) and many counties have already succeeded in implementing NPÖ [20]. Sweden has considerable control of information in regards to Child Health Data, Electronic Birth Registration and Medical Certificates, National Prescription Data Base (NOD)/ Nitha (National IT support for event analysis) Swedish Drug Information Database (SIL), etc. which allows fairly high degree of good quality management.
Many other eHealth services are available to citizens. Services such as websites ${ }^{1}$ that provide information about how to access special treatment types in the country and abroad, disease prevention campaigns and, among other tasks, allowing patients to book and cancel appointments. The private sector is also quite active in developing eHealth devices. For example, Ericson has developed $\mathrm{EMH}^{2}$ (Ericsson Mobile Health) that supports remote patient monitoring that contributes to reducing pressure on hospital beds.

\section{FUTURES STUDIES TO PLAN FOR SUSTAINABILITY}

Uncertainty challenges institutional structures, threatens coherence and could lead institutions to collapse when the unforeseen takes place [21]. Identifying potential difficulties and barriers may be a method of identifying opportunities to deal with uncertainties.

Future studies can help to change uncertain futures into opportunities to achieve desirable futures [22]. Scenarios systematically explore uncertainties, which are inherent in the process of looking at the long-term future. They are not intended to be realistic but provocative and helpful in strategy formulation and decision making [5]. Different, plausible futures are assembled through coherent description that integrates knowledge, allowing the comprehension of complex issues [23]. Consequently, scenarios support understanding of how social, economic and ecological systems interact with each other in particular settings.

Considering multiple futures is also a way of democratising planning and avoiding unipolar planning practices that focus on producing policies that provides privileges for the future of particular social groups but overlooks the futures of others. Alternative futures are also beneficial to challenging the status quo and unveiling alternative strategies and policies to deal with recurrent problems that have not been solved using traditional policies. [24]

Börjeson [25] makes a distinction between three categories of scenario studies: predictive (what will happen?), explorative (what could happen?) and normative (how can a target be fulfilled?). These types of scenarios have different purposes in studies that deal with sustainability. Predictive scenarios are useful to warn about what would happen if unsustainable trends continue into the future [26]. Explorative scenarios deal with several developments and so create opportunities for discussion and indication of tools and policies to counteract unsustainable futures. Normative scenarios are used when a sustainable target must be reached. In this case the starting point is a desirable future and from this future, policies and tools are designed and implemented retroactively [27].

The future can be constructed and reconstructed in several forms. However, the exercise of assembling alternative futures

1 http://www.1177.se/Stockholm/?ar=True

${ }^{2}$ http://www.ericsson.com/hr/ict_solutions/e-health/emh/ 
provides space for reflections that would otherwise be difficult. Exploring the future of the education and health sectors can increase capacity to plan for uncertainties and, consequently, work for sustainability.

\section{METHOD}

Education and health were among many other subjects (e.g. consumption patterns, governance, working patterns, financing, etc.) that were studied to support the development of comprehensive descriptions of five ICT futures for Sweden in 2060, as part of the project "Scenarios and Impacts of the Information Society (S\&I)" [28]. The S\&I project explores the global sustainability implications of Swedish ICT scenarios. Partners in the project are City of Stockholm, Ericsson, Interactive Institute, KTH, TeliaSonera and the Stockholm County Council (TRF).

From May to September 2013 a literature study covering historical developments, current situation and trends in the education and health sectors in Sweden was carried out. The prospective futures of education and health, here termed scenario elements, were then explored based on drafts of scenarios for ICT futures for Sweden (see description below). With the aim of narrowing the scope of the scenario elements, a literature study of existing explorative scenarios that dealt with the futures of education and health in relation to ICT was carried out. The scenarios ' 2020 and beyond: Future Scenarios for education in the age of new technologies' [29] and 'Health Technology Scenarios' [30] were selected due to their scope, scale and the European context in which they were developed. In January 2014, the scenario elements were discussed and revised in a workshop with the participation of academics and practitioners in the ICT sector.

\section{A. Description of the ICT futures and existing scenarios for} education and health

Short descriptions of five ICT futures for Sweden controlled the construction of the scenario elements on education and health. These brief descriptions were based on leading ideas that correspond to different trends and uncertainties already perceived today as concerns the influence of ICT on society. A synthesis of these descriptions is presented below:

- Economic decline: the economy in Sweden has halted and even shrunk compared to 2015. In a tough economic situation, people spend relatively more of their income on ICT.

- Trust in local and digital communities: trust in the unknown has dissolved and the importance of families and close networks has increased. There is a strong division between groups both physically and on the Internet.

- Life online: people live most of their lives online, and this is where they search for affirmation, status and to develop their identity. Wealth in terms of objects is less interesting.

- Controlling for convenience: a world of convenience where ICT supports all sorts of decision making and everything and everybody is connected. People find the value of the service they get worth the price of giving up their integrity.

- Valuing the environment - ICT has been consciously directed towards finding solutions to environmental problems, such as collaborative consumption. An emission rights system, through an additional currency called 'environrights' has been implemented on the individual scale.

Two other scenarios that explore the future of education and health were also used to support the development of the scenario elements. Looking at the future of education in 2020 the UK government developed five scenarios that focus on the interface between digital and biometric developments [29]. These scenarios explored consequences for the future of education in light of different ICT uses such as: ICT embedded in personal devices, in intelligent environments, ICT capacity for storage and processing data and security issues.

Focusing on the use of wireless in health care, a research group on behalf of the Office of Communications of the UK Government explored the future of technology in the health sector in UK for 2027 [30]. The scenarios were structured in two dimensions: (i) economic growth and funding / technological progress and (ii) structure of the health care/ personal engagement with health / use of information. The combination of these dimensions varied in magnitudes that ranged from high to low and resulted in five scenarios called (1) everything in abundance (2) everything in moderation; (3) divergence, (4) health service makes good, (5) stagnation.

\section{RESULTS}

The scenario elements were a result of the interplay between the scenarios described above. Table 1 summarises the features of the specific scenarios for education and health that were considered in order to develop the scenario elements in relation to the ICT futures.

Table 1: Scenario elements: interplay between the scenarios

\begin{tabular}{|l|l|l|}
\hline Scenarios & ICT in education [29] & ICT in health [30] \\
\hline $\begin{array}{l}\text { Economic } \\
\text { decline }\end{array}$ & None & $\begin{array}{l}\text { Few R\&D } \\
\text { investments due to } \\
\text { low profits in the ICT } \\
\text { sector; health system } \\
\text { remains unchanged }\end{array}$ \\
\hline $\begin{array}{l}\text { Trust in } \\
\text { local \& } \\
\text { digital } \\
\text { communities }\end{array}$ & $\begin{array}{l}\text { Identity is tied to } \\
\text { biometrics. The system is } \\
\text { secure and trustful, } \\
\text { enhancing cooperation. } \\
\text { But it also creates separate } \\
\text { environments for children } \\
\text { and adults }\end{array}$ & $\begin{array}{l}\text { Information in the } \\
\text { health system is } \\
\text { patchy; no sharing of } \\
\text { information among } \\
\text { patients. }\end{array}$ \\
\hline Life online & $\begin{array}{l}\text { Huge capacity for data } \\
\text { processing and storage }\end{array}$ & $\begin{array}{l}\text { Integration of health } \\
\text { systems }\end{array}$ \\
\hline $\begin{array}{l}\text { Controlling } \\
\text { for }\end{array}$ & $\begin{array}{l}\text { The use of ICT is } \\
\text { imperceptible as it is }\end{array}$ & $\begin{array}{l}\text { ICT enables efficient } \\
\text { restructuring of the }\end{array}$ \\
\hline
\end{tabular}




\begin{tabular}{|l|l|l|}
\hline convenience & $\begin{array}{l}\text { embedded in personal } \\
\text { devices (key, clothes, } \\
\text { shoes) }\end{array}$ & $\begin{array}{l}\text { system; use of ICT to } \\
\text { monitor people's } \\
\text { health }\end{array}$ \\
\hline $\begin{array}{l}\text { Valuing the } \\
\text { environment }\end{array}$ & None & $\begin{array}{l}\text { People are } \\
\text { responsible for their } \\
\text { own health; emphasis } \\
\text { on prevention and } \\
\text { social inclusion and } \\
\text { integration of health } \\
\text { services }\end{array}$ \\
\hline
\end{tabular}

\section{A. Scenario elements for education and health, Sweden 2060}

\section{Economic decline}

Education: advances in digital interface and management in the education sector are hindered by lack of technological development; consequently education practices use oldfashioned technologies. The Swedish educational system changes significantly. Pre-schools are not supported by the government; instead extended family members take care of the children. Education is important and schools are located according to communities' population (size and structure). Basic education is dependent on community members' skills, which shape the quality of education differently in different places. The number of upper secondary schools and universities decrease as do the number of teachers and students. Lack of economic growth discourages students to pursue higher qualifications. Valuable knowledge is regarded to be solutions to daily life problems.

Health: The Swedish National Health System is unable to deliver efficient care. Reactive rather than preventive care is dominant. Age expectancy drops. Primary care is performed at neighbourhood level. The number of hospitals declines. Specialised treatments are offered in a few Swedish cities. Lack of benefits from ICT use in health (lower costs, reduction of errors, rapid processes, etc.) implies that more employees are necessary in the sector. Nevertheless this does not happen. Instead voluntary services at community level attempt to deal with easy-to-handle, urgent problems. Information about healthy life styles (diet, physical exercise, etc.) is disseminated in workshops organised by communities. Alternative medicine, especially those available from the closest natural sites, are used.

\section{Trust in local and digital communities}

Education: The Swedish educational system is fragmented. Local communities provide pre-schools and basic education; so quality depends on their power to attract good teachers and to afford gadgets and safe networks to deliver a good education. This development endangers equity and justice in education. Secondary and tertiary level education is controlled by the government. Severe segregation between different groups in society prevents ICT advancements in education. Threats in virtual space constrain assessment practices, limit students' use of information and hinder the development of digital social skills. The use of ICT in education is guided by biometric data, which does not assure a fully safe environment. Innovation in educational technology is hindered by lack of collaboration.

Health: Concerns about privacy and security networks stop structural change in the National Health system. People do not trust monitoring devices and are afraid of wrong diagnoses and prescriptions. There is no integration between different authorities in the sector which prevents the full understanding of patients' health status. Most communities manage their primary care but only the government offers specialised treatments. Nevertheless, the greater part of social security and healthcare systems are provided and performed by private parties and/or public private partnerships. Only communities that can afford the safest providers can rely on eHealth services.

\section{Life online}

Education: Life online transforms basic principles in education enabling the emergence of new forms of interaction and knowledge production. Reading and writing skills are not important any longer since audio, video and podcasts support the acquisition of knowledge. A multitude of tools for eLearning engage students in virtual and immersive worlds. Teachers work together with technicians to develop new tools. Education is tailor-made according to students' needs. Almost everyone has access to education. The number of upper secondary schools, universities decreases. Institutions for basic education also decrease and diminish in size since pupils only regularly attend school for the first few years. The need for pre-schools remains.

Health: High connectivity generates a prosperous environment to increase eHealth technology. Government succeeds in providing an integrated digital platform that register, monitors people's medical histories. Most cases are easily treated. By saving public costs in the long run, eHealth techniques are improved and many people in Sweden have a personal eHealth digital device connected to the neighbourhood medical centre that keeps track of people's wellbeing. Preventive care diminishes the need for hospitals, hospital beds and employees. Primary care is offered in each neighbourhood. The iGeneration suffers from physical isolation and social unease: people have difficulty in communicating face to face; physical encounters cause anxiety and discomfort. Nevertheless the virtual environment promotes inclusion and integration among people.

\section{Controlling for convenience}

Education: The role of ICT in everyday life has transformed educational principles. The concept of intelligence concerns skills people need to deal with technology, which are many and are always changing due to the high pace of innovation. New practices, institutional arrangements and human interaction emerge to support learning. Education is tailormade according to pupils' strengthens and weaknesses. Educational environments are reshaped: different information can be displayed on walls; different levels of stimulus can be 
made visible; temperature, air pressure and light can be changed to serve different purposes.

Health: Government delivers high quality health service. A variety of personal devices are developed and used by people. With these devices people are not only constantly aware of their health conditions but also receive advice on how to improve their health. Innovation in the pharmaceutical industry brings significant progress on the treatment of previously chronic diseases. People live longer, healthier lives. Most people are healthy not because they have taken a decision to be so but because they are told what to do. ICT monitors people's behaviour and health habits. The number of hospitals and health care centres decrease. Most patients are treated at home except for chronic or terminal illness. There is no need for pharmacies since medicines are sold from machines, like ATMs.

\section{Valuing the environment}

Education: Education is well supported by ICT, but educational principles have not changed. Students go to school regularly, not because it is necessary for learning but because it is a way of socialising and cooperating with others. High connectivity between educational institutions worldwide supports platforms for learning about the environment. Pre and primary physical schools are necessary but online education dominates at secondary and tertiary level. Meetings between students and teachers are scheduled to support social interaction, but schools and universities decreases in number and size. Production and consumption of goods and services is one of the main subjects in education. Different fields explore this subject as a means of raising awareness about environmental costs, leading to less consumption. It also shapes research in the ICT sector. It focuses more on environmentally-friendly materials than on technological advancement.

Health: The eHealth concept is extended to the environment. People acknowledge that the environment mediates their existence and that 'they stay here just for a while' therefore eHealth devices are developed only if their life cycle environmental impact offsets energy consumption, CO2 emissions etc. Health is preventive and ICT is used to monitor and control people's condition. Web portals with integrated information about individuals' health status and services are implemented. This helps to decrease travel and save public financial resources that are spent on the environment. 'Less is more' is the dominant ideology. People are committed to the environment and their own health (healthy eating habits, daily exercise such as biking or jogging to work). This decreases the need for hospitals and neighbourhood care centres.

\section{REFLECTING ON THE FUTURE OF EDUCATION AND HEALTH}

In this section the transition of the education and health sectors towards the different futures is discussed in relation to ICT and sustainability. The role of ICT in these futures can be understood as preservative, transformative and supportive. In the 'economic decline' and 'trust in local and digital communities' scenarios, the use of ICT in education and health remains similar to today and, as such, the ICT role is preservative. On the other hand ICT substantially transforms the practices in both sectors in the 'life online' and 'controlling for convenience' futures. In the 'valuing the environment' scenario, technology supports the fulfilment of the Swedish sustainable environment objectives, but does not directly change practices in education or health.

Even though the technological sector does not develop in the 'economic decline' scenario, ICT is a feasible alternative for providing basic services to society. Nevertheless high costs of devices and maintenance are expected to threaten the efficiency of the system. Physical and virtual segregation in the 'trust in local and digital communities' scenario leads to uneven use of ICT that varies according to the economic conditions of the different communities and thus influences the quality of education. In 'life online' and 'controlling for convenience' scenarios ICT is available and used by all. In these futures, ICT transforms both sectors substantially. In the 'valuing the environment' scenario people consume less and are aware of environmental problems but they nurture social values that are currently conceived as worthy of a good society, therefore some of the teaching and health care practices remain the same as today as a means of encouraging social interaction.

Different reasons lead the scenarios 'economic decline' and 'trust in local and digital communities' to maintaining similar educational practices as used today. Civil society is the main provider of education in both futures. The poor economic performance in the 'economic decline' scenario and the socioeconomic heterogeneity of the different communities in 'trust in local and digital communities' is expected to hinder advancement in ICT. A weak state and lack of economic resources suggests that integration between different sectors of the education and health systems would not prevail in a future of economic debility. In the 'trust in local and digital communities' future, inequalities in education, especially accessibility and quality, are expected to arise between different social groups. Nevertheless the state takes the responsibility for secondary and tertiary educational levels, which might increase the opportunities for members of less prosperous communities to catch up with the others. Similar development occurs in relation to health as the responsibility of provision follows the same path: communities administer basic health care but the state is responsible for specialised care.

These futures address challenges to counteract the inefficiencies, as well as minimise the divides, related to accessibility, affordability and quality in the education and health sectors. In these futures, ICT could enhance new forms of civil organisation assuming an important role in politics. ICT could empower civil society through mechanisms for interaction and participation that would contribute to build up social capital and foster social activism unveiling alternatives to managing education and health issues on smaller scales [31]. Shared virtual spaces could be a platform where the 
differences meet and interact creating rich political spaces for debate and deliberation. The positive use of ICT could shift differences and segregation into diverse and rich spaces for politics.

The loss of meaning of physical spaces in favour of a rich and complete virtual existence in 'life online' results in significant changes in the education and health sectors. The government might provide basic online education, which is likely to focus on training individuals to select relevant information for their own purposes and interests rather than the learning traditional skills of writing and reading. So individual's interests are likely to shape their education, suggesting a greater diversity of expertise, but also uneven quality. In this scenario unofficial channels of education (e.g. TED a non-profit organization that provides a platform for experts in various areas) will probably expand. In a future where there is a radical change related to social values and behaviour - low levels of materialism and consumption and sporadic use of physical spaces - it could be argued that knowledge on how to fully enjoy a virtual life might be one of the most valuable skills. In contrast, ambitions concerning building a carrier are likely to be low since this future depicts a more equalitarian society that works much less and enjoys a lot of free time, released from the pressure of earning qualifications. In this future new challenges are likely to emerge that transcend accessibility to education, not only between those who know how to use technology and those who do not, but also between those who use technology to acquire relevant knowledge for education and those who use it for other purposes [32]. The overload of online information and high storage and processing capacity of new devices may also disclose new dimensions and competences that must be developed in order to use technology to accomplish personal and collective needs.

Life online is also a challenging future for the health sector. In a future where physical space, and possibly also the shape of human body, would not be important, maintaining good health appears difficult. Nevertheless, at the same time that ICT is the cause, it is also the solution to counteract health problems that arise from inactive physical routines. Online warnings to virtually join physical activities and advice about a balanced and healthy intake of calories and vitamins are some of the strategies to counteract non-mobile habits. Consequently this scenario presupposes a very efficient and advanced governance system with monitoring of information about individuals' health. Prevention is a key concept to assuring good health. Treatment of chronic diseases is feasible through the use of devices for monitoring. Since people are accustomed and enjoy living online, challenges to the implementation of eHealth practices such the consequences of changing the doctor-patient relationship from face-to-face interaction which today is important for healing, to health and wellness supported 365 days/year [33] will possibly not upset the system. One dark side of the loss of physical social interaction is the iDisorders [34] [35], which have been identified and discussed in literature as social phobias that emerge as consequence of the negative relationship between technology usage and psychological health. Nevertheless, the 'life online' future depicts a society in which face-to-face contacts are secondary, suggesting that social values and norms have changed and as such the concept of 'mental health' is likely to have quite a different meaning to what it has today.

Despite radical social changes in the 'life online' scenario, the education and health sectors are very efficient since both are accessible to everyone everywhere at any time. Nevertheless this future also raises important challenges at societal level in which knowledge about the benefits and hazards of the cyber world should be further expanded. If life is going to primarily take place in virtual spaces, one important question to address is how to foster 'good digital citizens' who use virtual spaces safely and responsibly.

Masses of information gathered by sensors that inhabit environments and are interconnected to personal devices in the 'controlling for convenience' scenario poses many challenges to the future of education. Nevertheless, in this scenario high levels of technological development do not imply radical social change as they do in 'life online'. As today, consumption is high and people interact actively with each other in physical spaces. Contrary to 'life online', in this scenario education at all levels is controlled by the government and thus operates within an official institutionalised structure that implies a common curriculum for all students. Despite similarities to the current educational system in terms of regulations; high level of technological development and interconnectedness between people and things raises many challenges for the future of education. How teaching practices would evolve in immersive environments raises issues related to the evaluation of students. Who or what should be tested in exams? The student, the student and the devices or the skills of the student using the devices? [29]

In this future the use of ICT is inconspicuous. Personal devices interact with intelligent environments that sense alterations of humour, blood pressure, temperature, etc. The environment knows everything and without realising it, people are constantly advised to maintain good health. This future is also efficient in the treatment of chronic diseases, which is supported by mobile monitoring health devices. Nevertheless this massive capacity to gather and process information could threaten privacy and confidentiality. Access to information about individuals' health could be abused leading to social discrimination (e.g. individuals might be dismissed from jobs due to poor health status).

In the 'valuing the environment' scenario, the ICT sector focuses on solving environmental problems in which ubiquitous technology is applied for low resources usage. Despite high levels of technological development, traditional practices of primary education and healthcare are maintained. Keeping primary schools and enhancing doctor-patient faceto-face relationships are means of nurturing beneficial social values. In this future, the education and health sectors are provided by the government therefore the quality of both 
services is quite even. Economy is steered by the environrights which, together with financial system, regulates personal consumption. ICT innovations in both sectors would possibly not be as fast as they are today, since environmental concerns would be the main driver of the economy. Nevertheless, the use of ICT in intermediate and higher level education might challenge the role of teachers who are likely to become an instructional manager helping to guide students through individualised learning pathways.

Table 2 summarises the main challenges and some strategies that could lead to the more sustainable transitions of the education and health sectors in the different futures. Read the table as follow: A (ICT role), B (Scenarios), 1 (End of Economic Growth), 2 (Trust in Local and Digital Communities); 3 (Life Online), 4 (Controlling for Convenience) and 5 (Valuing the Environment).

Table 2: Scenarios' challenges and strategies

\begin{tabular}{|c|c|c|c|}
\hline $\mathbf{A}$ & B & Challenges & Strategies \\
\hline . & $\begin{array}{l}1 \\
\& \\
2\end{array}$ & $\begin{array}{l}\text { - Civil society is the main } \\
\text { provider of basic education } \\
\text { and health; } \\
\text { - Weak governance: no } \\
\text { integration between sectors } \\
\text { of the education and health } \\
\text { systems; } \\
\text { - Uneven accessibility, } \\
\text { affordability, quality and } \\
\text { efficiency }\end{array}$ & $\begin{array}{l}\text { - Enhance ICT alternatives } \\
\text { to manage education and } \\
\text { health at lower levels. }\end{array}$ \\
\hline $\mid$ & 3 & $\begin{array}{l}\text { - High ICT dependence; } \\
\text { - Uneven quality in } \\
\text { education; } \\
\text { - New divides: use } \\
\text { technology to acquire } \\
\text { knowledge for education } \\
\text { and for other purposes; } \\
\text { - Difficulties in } \\
\text { maintaining good physical } \\
\text { health; } \\
\text { - Risk of physical isolation } \\
\text { and social unease }\end{array}$ & $\begin{array}{l}\text { - Develop resilient ICT } \\
\text { systems; } \\
\text { - Develop new competences } \\
\text { to deal with lots information, } \\
\text { high storage and processing } \\
\text { capacity; } \\
\text { - Enhance virtual interaction } \\
\text { between doctor-patient; } \\
\text { - Create platform for patients } \\
\text { to discuss their illness }\end{array}$ \\
\hline$E$ & 4 & $\begin{array}{l}\text { - High ICT dependence; } \\
\text { - Changes in teaching } \\
\text { practices; } \\
\text { - Threatens privacy and } \\
\text { confidentiality }\end{array}$ & $\begin{array}{l}\text { - Develop resilient ICT } \\
\text { systems; } \\
\text { - Develop teaching practices } \\
\text { in immersive environments; } \\
\text { - Establish ethical standards } \\
\text { for the use of ICT }\end{array}$ \\
\hline مإ் & 5 & - New role for teachers. & - Develop new competences. \\
\hline
\end{tabular}

\section{FINAL CONSIDERATIONS}

This study explored the future of the education and health sectors in relation to five ICT 2060futures for Sweden. The scenarios provided different perspectives of how society, economy, culture and politics could evolve and, as such, they mediate discussions about the relationship between people and ICT in different futures.

The sustainability debate in these futures focused on issues of accessibility, affordability and quality levels of the education and health sectors. Nevertheless, this debate overcomes expectations of 'haves and have-nots' and addresses complex questions that cannot be easily answered. For example, abundance of information does not imply better education but instead sheds light on the importance of developing skills and knowledge to cope with this profusion. Unequal amount of resources does not directly determine the establishment of divides as people might take advantage of digital technologies and services differently. Consequently the discussion of sustainability requires a multi-dimensional understanding of the relationship between ICT and society that overrides the assumption that technology per se is the solution.

This study does not present conclusive answers but hopefully has stimulated discussion about how socio-cultural and political aspects of the different ICT futures would interact in the education and health sectors, shedding light on sensitive issues that deserve the attention of the ICT community. The vulnerability of ICT technologies, blind reliance among users and the lack of mechanisms of participation to legitimise how private organisations shape the future of society, suggest that the enforcement of ICT solutions must include ethics and special care must be taken in these vital sectors of society.

The scenario elements on education and health were one of many methodological steps to assist the design of broader ICT futures. There are, however, two methodological limitations that should be pointed out here. First, the specific scenarios [29] [30] that were used to assist the elaboration of the scenario elements, envisioned the future of education in 2020 and health in 2028, while the scenario elements target futures in 2060. Second, the scenario elements have been presented and discussed in a single workshop with the participation of project partners. However, their elaboration could have benefited from a discussion with stakeholders from other groups (teachers, pupils, doctors, patients, vulnerable groups etc.) who are directly involved in both sectors.

Still, futures studies has proven to be an efficient method of bridging the gap between rapid technological development and its consequences to society. By presenting alternative futures, I believe these scenarios assisted discussion about possible societal value changes and, as such, they have created a space for reflection related to the future of the education and health sectors that otherwise would have been difficult to achieve.

\section{Acknowledgements}

This paper is a part of the Scenarios and sustainability impacts of ICT-societies project. Funding for this project comes mainly from VINNOVA - the Swedish Innovation Agency. 


\section{REFERENCES}

[1] M. Wolske, N. S. Williams, R. Y. Duple, E. O. Johnson and S. U. "Noble Effective ICT Use for Social Inclusion" (year). Online, available at:

https://www.ideals.illinois.edu/bitstream/handle/2142/14952/wolske.pdf ?sequence=2’ Retrieved, February 2015

[2] J. A. S. Laitner. "The Energy Efficiency Benefits and the Economic Imperative of ICT-Enabled Systems" in ICT Innovations for Sustainability, Advances in Intelligent Systems and Computing Volume 310, 2015, pp 37-48

[3] M. Mutchek and E. Williams. "Moving Towards Sustainable and Resilient Smart Water Grids" in Challenges 2014, 5(1), 123-137; doi:10.3390/challe5010123

[4] P. Tsatsou. "Digital divides revisited: what is new about divides and their research?” in Media, Culture \& Society 2011, 33(2) 317-331 DOI: $10.1177 / 0163443710393865$

[5] A. Wiek, C. Binder, and R. W. Scholz. "Functions of scenarios in transition processes” in Futures, 2006 38:740-766. Doi:10.1016/j.futures.2005.12.003

[6] E. L.; Glaeser, G. A. M. Ponzetto and A. Shleifer. "Why does democracy need education?” in Journal of Economic Growth 2007, 12:77-99. doi: 10.1007/s10887-007-9015-1

[7] T. Besley, and M. Kudamatsu. "Health and democracy” in American economic review, 2006, 96 (2). pp. 313-318. ISSN 0002-8282. DOI: $10.1257 / 000282806777212053$

[8] M. Rosenberg. "Health geography I: Social justice, idealist theory, health and health care” in Progress in Human Geography. 2014, Vol. 38(3) 466-475. DOI: 10.1177/0309132513498339

[9] M. G. Carmona, and J. A. Marin. "ICT trends in education” in 1st Annual International Interdisciplinary Conference, AIIC 2013, 24-26 April, Azores, Portugal. Online, available at: http://eujournal.org/index.php/esj/article/viewFile/1355/1364. Retrieved, December 2013

[10] Eurydice. "Key Data on Learning and Innovation through ICT at School in Europe". Education, Audiovisual and Culture Executive Agency, 2011. Online available at: http://eacea.ec.europa.eu/education/eurydice/documents/key_data_series /129EN.pdf. Retrieved on December 2013

[11] L. Henry. "Information and communications technology for future health systems in developing countries” in Social Science \& Medicine 66 (2008) pp. 2122-2132

[12] R. Milestad, Å. Svenfelt, and K-H. Dreborg. "Developing integrated explorative and normative scenarios: The case of future land use in a climate-neutral Sweden.” Futures 60 (August 2014) 59-71

[13] European Schoolnet. "Survey of Schools: ICT in Education Country profile: Sweden”. University of Liege, 2012. Online available at: https://ec.europa.eu/digital-agenda/sites/digital-

agenda/files/Sweden\%20country\%20profile.pdf.Retrieved on September 2013

[14] Gartner. "eHealth for a Healthier Europe! - Opportunities for a better use of healthcare resources", 2009. Online, available at: http://www.calliope-

network.eu/Portals/11/Swedish\%20EU\%20Presidency\%20Report\%20\%20eHealth\%20for\%20a\%20Healthier\%20Europe.pdf. Retrieved on January 2014.

[15] OECD. "Study on Digital Learning Resources as Systemic Innovation: Country case study report Sweden", 2009. Online, available at: http://www.oecd.org/sweden/42159200.pdf. Retrieved on November 2013

[16] Ministry of Enterprise Energy and Communication Sweden. "ICT for Everyone - A Digital Agenda for Sweden”, 2011. Online, available at: http://www.government.se/content/1/c6/18/19/14/70f489cb.pdf. Retrieved in September 2013

[17] L. Häggmark. "Priority Areas Report - Education Sweden” in Central Baltic Living Labs for Digital Services, 2012. Central Baltic INTERREG IV A Programme 2007-2013.
[18] A. Amft. "Higher education in Sweden”, Universitetskanslersämbetet 2014 Report number 2014:10. Online available at: http://english.ukambetet.se/download/18.7ff11ece146297d1aa65b4/higher-education-inSweden-2014-status-report.pdf. Retrieved in February 2015

[19] P. Doupi, E. Renko, S. Giest and J. Dumortier. "eHealth strategies. Country brief. Sweden”, 2010. Online, available at: http://ehealthstrategies.eu/database/documents/sweden_countrybrief_ehstrategies.pdf. Retrieved in August 2013

[20] L. Jerlvall and T. Pehrsson. "eHälsa i landstingen" (eHealth in the County Councils). 2011

[21] K. van der Heijden. "Scenarios: The Art of Strategic Conversation", Wiley, Chichester, 1996.

[22] A. Svenfelt. “Two strategies for dealing with uncertainty in socialecological systems.” Doctoral Thesis in Infrastructure with specialisation in Environmental Strategic Analysis, Royal Institute of Technology, 2010

[23] O. Sparrow. "Making Use of Scenarios - From the Vague to the Concrete”, in Scenario \& Strategy Planning, 2000, 2(5)

[24] J. von Oelreich, A. Carlsson-Kanyama, Å. Svenfelt \& P. WikmanSvahn. "Planning for future sea-level rise in Swedish municipalities". Local Environment: The International Journal of Justice and Sustainability, 2013

[25] L. Börjeson, M. Höjer, KH. Dreborg, T. Ekvall and G. Finnveden, G. "Scenario types and techniques - Towards a user's guide”. Futures vol. 34, pp. 723-739, September 2006

[26] M., Höjer, KH Dreborg, R. Engström, U. Gunnarsson Östling, and Å Svenfelt. "Experiences of the development and use of scenarios for evaluating Swedish national environmental objectives. Futures, 2010, doi:10.1016/j.futures.2010.02.005

[27] Å. Svenfelt and M. Höjer "Framtidsstudier och osäkerheter" in S. Alm, J. Palme and E. Westholm (eds) Att utforska framtiden: valda perspektiv, Stockholm: Dialogos, 2012.

[28] U. Gunnarsson, D. Pargman, M. Höjer, and L. A. Borges "Pluralising the future information society: Scenarios and sustainability impacts of ICT-societies”. Paper submitted to ICT4S 2015 (forthcoming).

[29] H. Daanen, and K. Facer. "2020 and beyond: Future scenarios for education in the age of new technologies." Futurelab, 2007. Online, available at: www.futurelab.org.uk/openingeducation. Retrieved on December 2013

[30] ?What if! Digital. "Health Technology Scenarios and Implications for Spectrum”, 2010.On line, available at: http://stakeholders.ofcom.org.uk/binaries/research/technologyresearch/healthtech.pdf. Retrieved in December 2013

[31] T. Dillahunt. "Fostering Social Capital in Economically Distressed Communities". Online, available at http://www.tawannadillahunt.com/wpcontent/uploads/2014/03/Dillahunt 905.pdf. Retrieved in May 2015.

[32] O. Erstad "Addressing the complexity of impact - A multilevel approach towards ICT in education” in Scheuermann, F. \& Pedró, F. eds (2009) Assessing the eff ects of ICT in education Indicators, criteria and benchmarks for international comparisons. European Commission, Joint Research Centre. On line, available at: http://browse.oecdbookshop.org/oecd/pdfs/free/9609111e.pdf. Retrieved on March 2014

[33] J. P. Wiener. "Doctor patient communication in the e-health era" in Israel Journal of Health Policy Research 1:33, 2012. Online, available at: http://www.ncbi.nlm.nih.gov/pubmed/22929000. Retrieved on March 2014

[34] L. D. Rosen, N. A. Cheever, and L. M. Carrier, "iDisorder: Understanding our obsession with technology and overcoming its hold on us”, 2012. New York, NY: Palgrave Macmillan.

[35] D. J. Kuss and M. D Griffiths. "Online social networking and addiction-A review of the psychological literature” in International Journal of Environmental Research and Public Health, 2011, 8(9), 35283552. doi: 10.3390/ijerph8093528 